\title{
DEPENDENCE OF FUEL CONSUMPTION ON WINTER RAPE STUBBLE TILLAGE QUALITY IN CLAY LOAM SOIL
}

\author{
Vidas Damanauskas \\ Lithuanian Research Centre for Agriculture and Forestry, Lithuania \\ damvid@gmail.com
}

\begin{abstract}
Oilseed winter rape is often replaced by winter wheat in benefit to crop rotation. The high-cut and rigid oilseed winter rape stubble with large roots mass often is the main challenge of clear post-harvesting shallow tillage, especially in clay loam soil at minimum expenditure of fuel consumption. In most cases the disc harrow is used to interblend the stubble and plant residues into soil. If the shallow tillage is done well, the mineralization takes place and winter rape stubble does not have the negative influence on the sowing of the next rotation crop. The aim of this study was to determine the dependence of fuel consumption that is required to achieve the preferred level of shallow tillage in clay loam soil after the harvest of oilseed rape. The fuel consumption was investigated with a disc harrow (4 m width), depending on the disc angle and forward speed. The investigated tractor "CASE IH 135" with dual wheels was equipped with a data acquisition system and was used to measure the fuel consumption, speed and implement draft. This research has developed the correlation of stubble and other plant residue incorporation ratio (from 0.47 to 0.86 ) to fuel consumption (from 2.7 to $5.91 \cdot \mathrm{ha}^{-1}$ ) that was dependent on the draft force of the aggregate regime. The sufficient post-harvest tillage quality level, in this case the plant residue incorporation ratio was taken into account, is possible to reach with the minimal fuel consumption per hectare, when the disc angle is $10^{\circ}$ at the working speed $3.5 \mathrm{~m} \cdot \mathrm{s}^{-1}$.
\end{abstract}

Keywords: disc angle, disc harrow, residue incorporation, shallow tillage, working speed.

\section{Introduction}

Oilseed rape is one of the most important crops for edible oil and a big part is used for biofuel production like renewable sources from agriculture, it is an important oil delivering crop. The oilseed rape production has risen up by $22.2 \%$, it has influence to the benefits of farmers [1]. Oilseed winter rape is often replaced by winter wheat of popular crop rotation. The period from winter rape harvest to winter wheat sowing, e.g. for preparation of soil, does not take 2 months in Northern Europe countries. An important impact on the growth of wheat crop and its yield is by proper cultivation of rape straw. Correct macro-porosity ensures the optimum water content; the smooth decomposition process of micro-organic is working well, when there is correct incorporation of straw and plant residues [2]. Correct oilseed rape straw incorporation for $\mathrm{C}$ and $\mathrm{N}$ mineralization, microbial biomass and extractable organic pools helps achieve high yields. However, the straw quantity plays a major role in excellent-microbe life productivity, microbial-related processes in the soil profile [3;4]. Inserting this huge amount of high-cut rape residue into the soil layer is an arduous process, particularly in clay loam, also it increases the draft requirement and fuel consumption [5]. Disc harrows are being widely used throughout the world in "simplified tillage". It is often recommended to save resources and to perform shallow soil loosening, pulverization, stubble cutting, weed control, incorporation of manure and orchard stubble cultivation. The straw length, amount and incorporation depth are the crucial factors, which affect the soil microbial community and various enzyme activities. It also has impact on the mineralization process. Decomposition of residues is faster, when the incorporation quality is better [6].

The quality of the shallow tillage depends on the soil structure. If the incorporation of stubble does not cause problems, while working on light loam soils, it is not always potentially well prepared in the hard-clayed soils. Clay soil is too hard to prepare for sowing other crops and tilling generally requires more passes [7]. Reduced number of passes is required for preparing soil with a powered disc carried out by Upadhyay, this rotavator can do well at the first pass with a reduction in the draft, slip, and decreases the clod size by $30-36 \%$, but it takes more time and increases the wear of the working parts and the implement [8]. The researches of the harrowing regime mode in soil bin were carried out by Ani O. A. et al. [9] and more realistic researches were carried out by Serrano J. M. et.al. under natural conditions with the use of different examples for harrowing, concerned only the definition of the pulling force and its influence on fuel consumption [10]. It can be stated that post-harvest tillage has a significant impact on the next following agricultural operation (ploughing, seeding and etc.), so it is important to do it properly for the quality of primary processing that must be in line with the high 
agronomic requirements. The fuel consumption is used to overcome the implement draft; therefore, it increases proportionally to the implement draught force and working speed [11-13]. Kogut et al. established that the draft demand is depending on the disc angle of the harrow as a tillage tool after harvest [14]. Higher work rates and lower values of fuel consumption per hectare were achieved with no visible difference in soil tilling by operating the disc harrow at a lower angle of the disc and shifting up to a higher gear ratio whilst maintaining the engine speed [15]. It is known that tillage is one of the largest farm's operations, as it requires the biggest part of fuel consumption in the crop production and a great part of the production cost; however, any optimization of the aggregate regime mode reduces expenditures $[16 ; 17]$.

\section{Materials and methods}

The heading of this paper is incorporation of plant residues into soil after tillage with the lowest fuel consumption required to achieve sufficiently correct quality of processing. Suspended compact disc harrow "Bury KBT-4" was used; it has 4 meters in width, mass $1750 \mathrm{~kg}$ and a possibility to change the attack angle of the disc (Fig. 1). The disc harrow is constructed from two rows of discs $(16+16)$, one row of tines and a spring-ring roller. The main advantage of this compact disc harrow is the working parts, the toothed discs suspended on individual springs. This is helpful in sinking the discs into even dried-out soil and it also protects them from damage. Harrows have adjustable pitch and an adjustable disc angle $\left(0^{\circ}\right.$ to $\left.25^{\circ}\right)$. The treatments were performed on winter oilseed rape stubble witch height was $20 \pm 3 \mathrm{~cm}$ a few days after the rape harvest in clay loam soil. The terrain conditions were established with a penetrometer, the iron cone nominal angle of $60^{\circ}$, mean penetration resistance at $10 \mathrm{~cm} 1.15 \pm 0.06 \mathrm{MPa}$. The soil water content was determined by the gravimetric method: at soil surface depth $0-10 \mathrm{~cm}$ it was $18.6 \pm 1.1 \%$. The tests were accomplished at fixed disc angles $10^{\circ}, 15^{\circ}$ and $20^{\circ}$, fixed tillage depth at $8 \mathrm{~cm}$. The implement was towed at the working speed: $1.4 ; 1.9 ; 2.5 ; 3.1$ and $3.6 \mathrm{~m} \cdot \mathrm{s}^{-1}$. The tests for each aggregate regime mode, e.g. tillage with the certain disc harrow adjustments (5 speeds, 3 angles, 2 depths) at all 30 modes of operation, were done with three replications. The tractor engine speed was fixed as field work at 1600 to $1700 \mathrm{~s}^{-1}$ and the tractor working speed was achieved by changing varied gears.
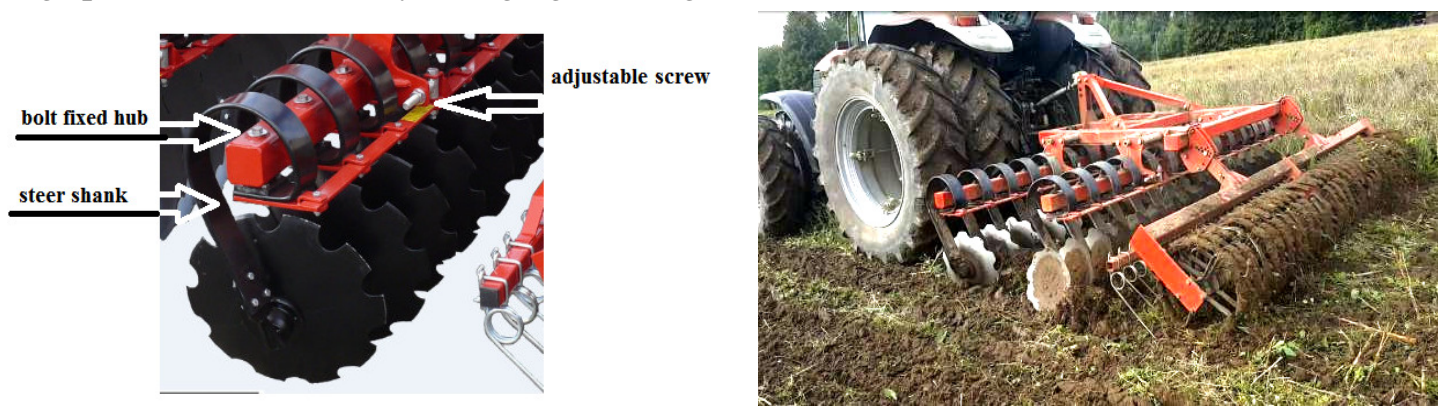

Fig. 1. Experimental aggregate compact disc harrow "KBT-4"

The measurements were done of: a) draft force, using standard pull-in fingers of the tractor; $b$ ) fuel consumption $\left(1 \cdot h^{-1}\right)$, by an added fuel consumption gauge, fuel cooler, fuel filter and air separator in the main fuel system of the engine; c) field speed of tractor, by an original speed radar of the tractor connected to the data recorder. The wireless from thrust fingers field speed radar and electrics generator were connected to the installed instrument system data recorder "SKRT-21 Lite" with the software "SKRT-MANAGER". The calibration of draft signals from thrust fingers was done by using the dynamometer load cells (PCE-FB 50k). Draft force was acting on the tractor, which simulated the resistance of the disc harrow. The draft strength was developed to such value that the signals of the traction sensors would correspond to the average signal strength recorder during the tests. The thrust fingers were loaded by several values of the draft force in the pulley traction direction. The electrical signal of the tractor's left and right fingers original load cell was writing to the data recorder. At the same time the dynamometer showed the draft force in Newtons. Indications from the recorder and dynamometer were paralleled. All data of the calibration test were displaced from the data recorder and graphic reliance was made. Hourly fuel consumption was measured by the fuel flow meter, which signals were recorded to the data recorder. The fuel flow meter was fitted into the low-pressure fuel supply system of the engine. Additionally, a fuel cooling radiator, filter and the air separator were 
installed to ensure correct fluency work of a fuel flow meter. The determination of fuel consumption and draft force of each treatment by three replications at the same aggregate regime adjustment was done. Fuel consumption per hectare $F C_{h a}$ was calculated according to the following equation [16]:

$$
F C_{h a}=\frac{F C_{h}}{0.36 \cdot \tau \cdot v \cdot W}, 1 \cdot h^{-1}
$$

where $F C_{h}$ - hourly fuel consumption, $1 \cdot \mathrm{ha}^{-1}$;

$W$ - working width of the implement, m;

$\tau-$ utility rate of the working width and time, not dimensional;

$v$ - working speed, $\mathrm{m} \cdot \mathrm{s}^{-1}$.

Fuel consumption per hectare was calculated only for the technological process of stubble harrowing, e. g. the headland turns of the aggregate were not included into the count. Engine rotation speed of the tractor was measured by using the signal from the electric generator. Built-in design speed radar of the tractor was used for measuring the working speed. All measurements were written in the data recorder. Data deviation did not exceed $2 \%$ and was based on the characteristics of the devices.

For assessment of the plant residue incorporation quality level the weight ratio method was used $[18 ; 19]$. Three plant residue samples from each treatment of the aggregate regime mode were taken manually before and after harrowing. All residues (winter rape stubble, straw and other residues, and weeds) were collected from the soil surface in the frame of $0.25 \mathrm{~m}^{2}(50 \times 50 \mathrm{~cm})$ in between and from both sides of the tracks of the combine harvester. All residues were dried and weighted to determine the residue mass before tillage, this mass was marked $-M_{t}$. After tillage not incorporated (visible) plant residues and their parts were collected in the same places and frame square. These residues were dried, weighted and this mass is marked $-M_{v}$. The quality of residue incorporation was estimated by the division of the plant residue mass incorporated into soil after tillage and the plant residue mass before tillage. According to similar studies [18;19], the value of residue incorporation was calculated as the ratio of incorporated plant residue mass and total residue mass before tillage is named as incorporation ratio and marked $k_{i}$ :

$$
k_{i}=\frac{M_{t}-M_{v}}{M_{t}}
$$

where $M_{t}-$ total residue mass before tillage, $\mathrm{kg}$;

$M_{v}$ - visible, not incorporated residue mass, collected from the tilled soil surface, $\mathrm{kg}$.

The measurement data of plant residue mass $M_{i}, M_{t}$ deviation (SD) did not exceed 5 percents of one agregate towing regime treatment. The statistical (ANOVA) analysis of the results showed significant differences between the aggregate regime mode combinations $\left(F>F_{c r i t}\right)$ of hourly fuel consumption (Fig. 3) and fuel consumption per hectare (Fig. 4).

\section{Results and discussion}

Adjustments of the implement make significant differences of plant residue mass quantity incorporation. The results showed that in purpose to obtain the high level of this incorporation operation at additional aggregate regime mode is needed. The incorporation residue ratio depended on the working speed and the angle of the disc. At a low working speed and small disc angle the level of incorporation quality was weak - big part of all plant residues were still on the surface. The plant residues were almost invisible in the treatments at a high working speed and sharp disc angle. Zero residues cannot be, when working on shallow depth with a disc harrow. It is noticeable that there is a limit on the residue mixing potential.

The disc angle has the strongest influence on the residue incorporation ratio: at $10^{\circ}$ degree and low working speed $\left(1.4 \mathrm{~m} \cdot \mathrm{s}^{-1}\right)$ the incorporation of plant residues was insufficient - when the disc angle was rising from minimal to maximal, the residue incorporation ratio $k_{i}$ increased from 0.47 to 0.76 (Fig. 2). Raising the disc angle from $10^{\circ}$ to $20^{\circ}$ and at maximum speed $\left(3.6 \mathrm{~m} \cdot \mathrm{s}^{-1}\right)$ the residue incorporation ratio $k_{i}$ increased from 0.8 to 0.86 . It can be seen that at a high working speed the disc angle has no significant effect on the straw incorporation ratio. The residue incorporation ratio $k_{i}$ 
reached the best value -0.86 , at the disc harrow adjustment: disc angle $-20^{\circ}$, working speed $3.0 \mathrm{~m} \cdot \mathrm{s}^{-1}$. When the disc angle was set at $20^{\circ}$ and the working speed reached the maximal value, the incorporation ratio of residues began to decrease, because the inertia forces of big rape roots and straw lob up and drop down on the soil surface.

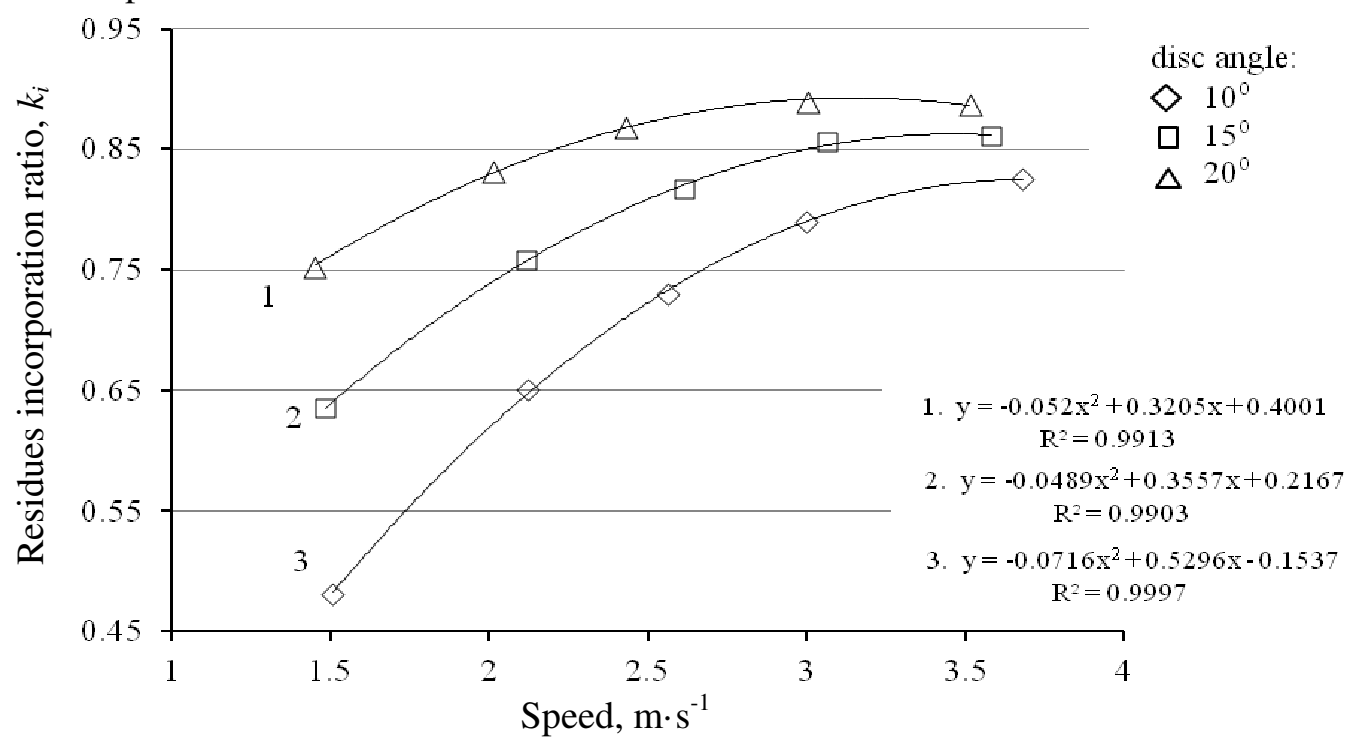

Fig. 2. Dependence of residue incorporation ratio on working speed

It is possible to work with a smaller disc angle, at the same time it is possible to get the same incorporation ratio of residues at higher speeds. Similar studies were conducted by Liu J. et al. (2010) and indicated that a higher speed of the tillage operation may reduce the residue cover. For sufficient incorporation of residues the achievable speed of the tractor must be considered, depending on the engine power and then the disc angle will be chosen, e.g., if impossible to reach sufficient speeds, it needs to increase the disc angle. The fuel consumption of the tractor required to draw the implement is proportional to the resistance force and the necessity of its power. The hourly fuel consumption is increased due to the increasing draft force. The measurements of the draft force were from 13 to $22 \mathrm{kN}$ by linear dependence to adjustable disc angle and working speed.

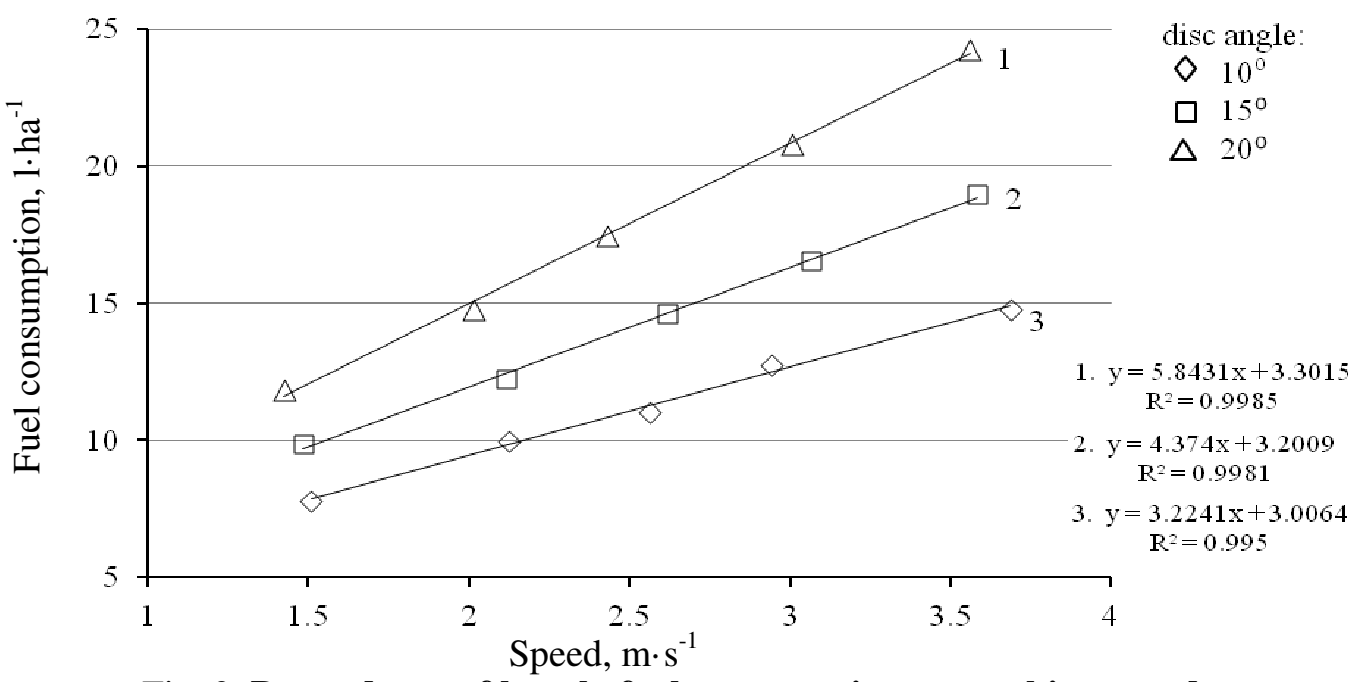

Fig. 3. Dependence of hourly fuel consumption on working speed

Figure 3 shows that the hourly fuel consumption is dependent more on the working speed, not on the disc angle, which explains that the resistance movement of the tractor itself requires higher fuel content and more energy is needed to overcome inertial soil jerk forces. When the speed was increased from 1.4 to $3.6 \mathrm{~m} \cdot \mathrm{s}^{-1}$ at the disc angle $10^{\circ}$, the hourly fuel consumption increased from 8.2 to $14.61 \cdot \mathrm{h}^{-1}$. When the disc angle was set from the smallest $\left(10^{\circ}\right)$ to the biggest $\left(20^{\circ}\right)$ value at minimal working speed $\left(1.4 \mathrm{~m} \cdot \mathrm{s}^{-1}\right)$, the hourly fuel consumption increased from 6 to $10 \mathrm{l} \cdot \mathrm{h}^{-1}$. When the working speed was maximum $\left(3.5 \mathrm{~m} \cdot \mathrm{s}^{-1}\right)$, the hourly fuel consumption was in the range from 15 to $25 \mathrm{l} \cdot \mathrm{h}^{-1}$ in 
dependence of the disc angle. The consumed hourly fuel consumption has direct dependence on tillage resistance. It can be noted that shallow tillage at high working speed in relation with higher tillage resistance has strong influence on the residue incorporation ratio level.

The fuel consumption of the tractor per hectare is better reflected efficiency of fuel usefulness in field works. Fuel consumption per hectare was investigated only for the technological process of stubble harrowing. It was found that fuel consumption differs in treatments by using the disc harrow adjustment and regime mode to obtain additional incorporation level. The fuel consumption per hectare increases by the increase of the disc angle, but decreases with increasing of the working speed. The results in Fig. 4 illustrate that it is possible to do shallow stubble tillage with the fuel consumption varied from 2.7 to $5.61 \cdot \mathrm{ha}^{-1}$, it depends on the selected work regime mode. When the disc angle was $10^{\circ}$, the fuel consumption was the smallest and the value fluctuated around $31 \cdot$ ha $^{-1}$; when the angle was $15^{\circ}$, it fluctuated around $41 \cdot \mathrm{ha}^{-1}$ and when the disc angle was set at $20^{\circ}$, the fuel consumption ranged around $51 \cdot \mathrm{ha}^{-1}$.

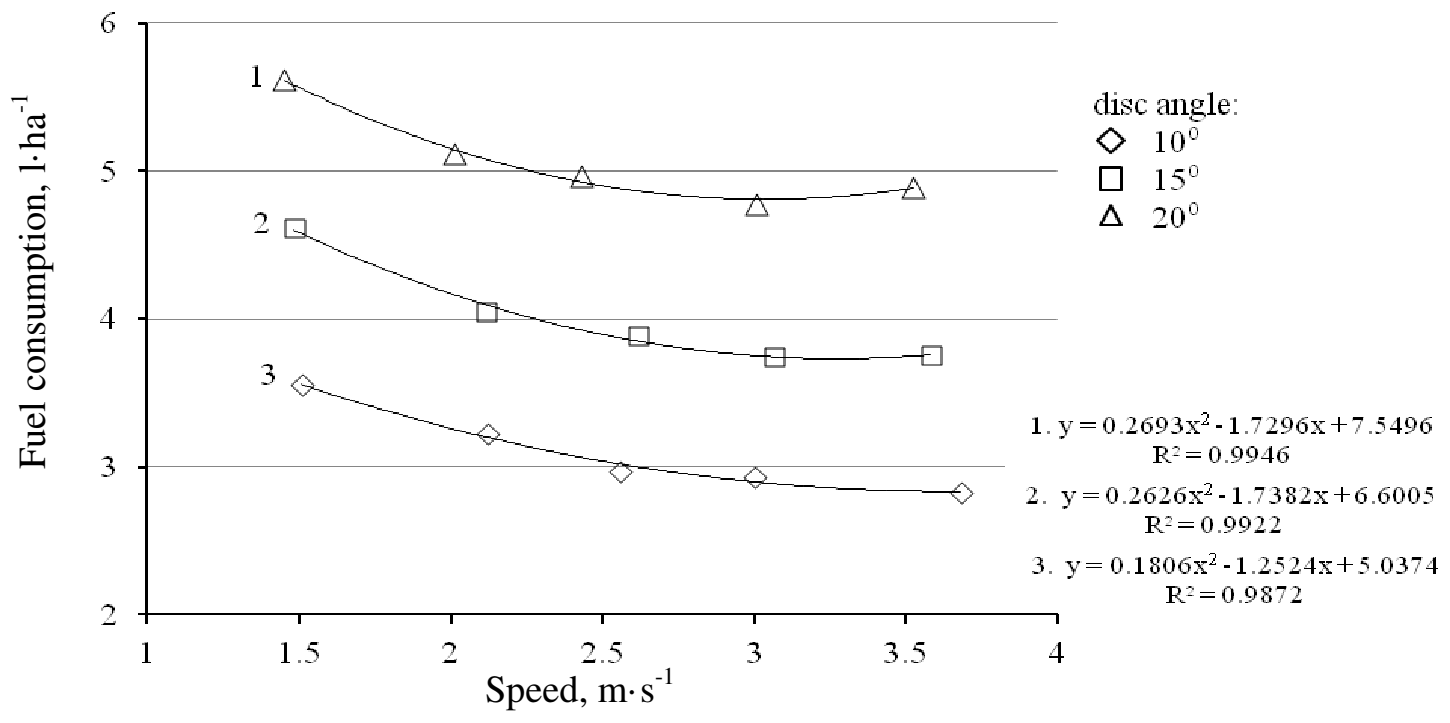

Fig. 4. Dependence of fuel consumption per hectare on working speed

The summary of the results illustrates that it is possible to do stubble tillage on clay loam soil with low fuel consumption obtained with a particular working speed and a small disc angle, but at the same time, incorporation of plant residues is weak and the residue incorporation ratio $k_{i}$ was low. The higher value of the residue incorporation ratio $k_{i}$ requires a higher level of fuel consumption. In case to best exertion of plant residues, it is needed to set the disc angle at $20^{\circ}$, at this angle the fuel consumption per hectare has the highest value at all speeds. The fuel consumption per hectare at the speed more to $3.1 \mathrm{~m} \cdot \mathrm{s}^{-1}$ begins to increase, it is explained due to the regime of excessive engine overload.

\section{Conclusions}

The results of this study may provide helpful indications for the appropriate choice of the tractor working speed and implement configurations, optimizing energy requirement on post-harvest shallow tillage, as a result it reduces the tillage costs.

1. Based on the results, the residue incorporation ratio varied from 0.47 to 0.86 and the best mean was obtained, when the disc angle was at $20^{\circ}$, the working speed from 2.7 to $3.1 \mathrm{~m} \cdot \mathrm{s}^{-1}$. Fuel consumption for the highest plant residue incorporation ratio was $-4.71 \cdot \mathrm{ha}^{-1}$.

2. The adjustment of the disc harrow and chosen working speed was influenced by the fuel consumption which varied from 2.7 to $5.91 \cdot \mathrm{ha}^{-1}$. The fuel consumption difference was $1 \mathrm{l} \cdot \mathrm{ha}^{-1}$ in dependence on the disc angle adjustment at the same speed. The fuel consumption difference was $1 \mathrm{l} \cdot \mathrm{ha}^{-1}$ in dependence on the working speed from minimal $\left(1.4 \mathrm{~m} \cdot \mathrm{s}^{-1}\right)$ to maximal $\left(3.6 \mathrm{~m} \cdot \mathrm{s}^{-1}\right)$ at the same disc angle.

3. The sufficient post-harvest shallow tillage quality level, in this case the residue incorporation ratio was considered, with the minimal fuel consumption per hectare, is possible to reach at the 
aggregate regime mode, when the disc angle is $10^{\circ}$ at the working speed $3.5 \mathrm{~m} \cdot \mathrm{s}^{-1}$; the fuel consumption was $2.71 \cdot \mathrm{ha}^{-1}$.

\section{Acknowledgement}

This research is supported by the research programme "Productivity and sustainability of agricultural and forest soils" implemented by the Lithuanian Research Centre for Agriculture and Forestry.

\section{References}

[1] Central Statistics Office (CSO) statistical release, 28 March 2018, [online][16.02.2019] Available at: https://www.cso.ie/en/releasesandpublications/er/aypc/areayieldandproductionofcrops2017/.

[2] Christian D.G., Miller D.P. Straw incorporation by different tillage systems and the effect on growth and yield of winter oats. Soil \& Tillage Research, vol. 8, 1986, pp. 239-252.

[3] Jensen L.S., Mueller T., Magid J., Nielsen N.E. Temporal variation of C and N mineralization, microbial biomass and extractable organic pools in soil after oilseed rape straw incorporation in the field. Soil Biology and Biochemistry, vol. 29, 1997, pp. 1043-1055.

[4] Ocio J.A., Brookes P.C., Jenkinson D. S. Field incorporation of straw and its effects on soil microbial biomass and soil in organic N. Soil Biology and Biochemistry, vol. 23, 1991, pp. 171-176.

[5] Karparvarfard S.H., Rahmanian-Koushkaki H. Development of a fuel consumption equation: Test case for a tractor chisel-ploughing in a clay loam soil. Biosystem Engineering vol. 130, 2015, pp. 23-33.

[6] Rong G., Ning Y., Cao X., Su Y. Evaluation of optimal straw incorporation characteristics based on quadratic orthogonal rotation combination design. The Journal of Agricultural Science, vol. 156, Issue 32018 , pp. 367-377

[7] Naderloo L., Alimadani R., Akram A., Javadikia P., Khanghah H.Z. Tillage depth and forward speed effects on draft of three primary tillage implements in clay loam soil. Food Agriculture Environmental, vol.7, 2009, pp. 382-385.

[8] Upadhyay G., Raheman H. Comparative analysis of tillage in sandy clay loam soil by free rolling and powered disc harrow. Engineering in Agriculture, Environment and Food, vol. 12, 2019, pp. $118-125$.

[9] Ani O. A., Uzoejinwa B.B., Ezeama A.O., Onwualu A.P., Ugwu S.N., Ohagwu C.J. Overview of soilmachine interaction studies in soil bins. Soil \& Tillage Research. vol. 175, 2018, pp. 13-27

[10] Serrano J. M., Peca J.O., Silva J.M., Pinheiro A., Carvalho M., 2007. Tractor energy requirements in disc harrow systems. Biosystems Engineering, 98, 2007, pp. 286- 296

[11] Van Linden V., Herman L. A fuel consumption model for off-road use of mobile machinery in agriculture. Energy, 77, 2014, pp. 880-889.

[12] Grisso R.D., Yasin M., Kocher M.F., 1996. Tillage Implement Forces Operating in Silty Clay Loam. Transactions of the ASAE. 39(6), 1996, pp. 1977-1982

[13] Iman Ahmadi. A draught force estimator for disc harrow using the laws of classical soil mechanics. Biosystems Engineering, 171, 2018, pp. 52-62

[14] Kogut Z., Sergiel L., Żurek G. The effect of the disc setup angles and working depth on disc harrow working resistance. Biosystems Engineering. 151, 2016, pp. 328-337.

[15] Serrano J. M., Peca J.O., Pinheiro A., Carvalho M., Nunes M., Ribeiro L., Santos, F. The Effect of Gang Angle of Offset Disc Harrows on Soil Tilt, Work Rate and Fuel Consumption. Biosystem Engineering vol. 84, 2003, pp. 171-176.

[16] Janulevičius A., Damanauskas V., Pupinis G. Effect of variations in front wheels driving lead on performance of a farm tractor with mechanical front-wheel-drive. Journal of Terramechanics, 77, 2018, pp. 23-30.

[17]Lovarelli D., Bacenetti J., Fiala M. Effect of local conditions and machinery characteristics on the environmental impacts of primary soil tillage. Clean Production. 140, 2017, pp. 479-491.

[18] Voßhenrich H.H., Brunotte J., Ortmeier B. Gitterrastermethode mit Strohindex zur Bewertung der Stroheinarbeitung. Landtechnik. 60, 2005, pp. 328-329.

[19] Voßhenrich, H.H., Brunotte, J., Ortmeier, B. Methoden zur Bewertung der Strohverteilung und Einarbeitung. Landtechnik. 58, 2003, pp. 92-93. 